Mohamed Farrag Ahmed Badawi

\title{
The Development of a Suggested Internationalized Curriculum for Egyptian Prospective EFL Teachers
}

Mohamed Farrag Ahmed Badawi

Curriculum \& EFL Instruction Dep., Faculty of Education, October 6

University, Egypt

\begin{abstract}
The Egyptian reform agenda targets the current Egyptian Teacher Education Curricula (ETEC). Reform should meet the national and international requirements. Accordingly, research attempted to evaluate the current English as a Foreign Language Teacher Education Curriculum (EFLTEC) and to suggest an Internationalized Curriculum for Egyptian Secondary School EFL Teachers' Preparation. The suggested curriculum was developed in light of the insights gained from analyzing nine referenced documents namely; the Sustainable Development Strategy (SDS), National Academic Reference Standards (NARS), American Council on the Teaching of Foreign Language (ACTFL), National Council for Accreditation of Teacher Education (NCATE), the Standards of the Council for Accreditation of Educator Preparation CAEP, the Australian Professional Standards for Teachers (APST), Cambridge English Teaching Framework (CETF), Sustainable Development Goals (SDGs) and $21^{\text {st }}$ Century Skills. Twenty six EFL fourth-year students participated in the pilot study and ninety six of the same majors and level participated in the main study. In addition, seventeen EFL experts participated in the study. The research project adopted the mixed research method so that document analysis technique, interview, questionnaire, Delphi technique, and focus group technique were used to collect the targeted quantitative and qualitative data. Results revealed that EFL majors $(73.9 \%)$ were not satisfied with the current EFLTEC in terms of meeting the national and international teacher preparation requirements. Document analysis resulted in stating seven EFL preparation curriculum standards integrating national and international against which an Internationalized Secondary School EFL Teachers' Education Curriculum was proposed.
\end{abstract}

Keywords: Teacher Education, EFL Education Curricula, National Curricula, International Curricula, Teachers' Preparation Standards, Education Reform in Egypt.

\section{Introduction}

Like many other courtiers Egypt is concerned with quality education. The initial step in developing quality education is to elevate the quality of preservice education or preparation. Pre-service teacher education programs are the first form of professional study that prepare individuals to complete to hold teaching as a profession. Nowadays, internationalization of education is central to actualize quality education. Teacher education curriculum of all disciplines could be internationalized, yet the amount of curriculum internationalization varies from one major to another. EFL teacher education (EFLTE) could be one of the most appropriate teacher education curricula for internationalization since some of the content courses of EFLTE are of international roots namely; literature, linguistics and culture. Most of these courses of the EFLTE are written and delivered 
in English and such Englishization facilitates the process of internationalization.

Regarding the education reform in Egypt, quality education is a means and an end. Yet "the quality of education cannot exceed the quality of teachers" (Kim, 2005, p.1). That is to say, the more the teachers are qualified, the higher the leaners' achievement is. Further, Borg (2018, p. 80) stated that "The quality of education that students receive is influenced by several factors, but key among these is the quality of their teachers." In addition, the quality of training provided through pre-service teacher education programs affects teachers' practice, effectiveness, and career commitment (Eren \& Tezel, 2010; Liang, Ebenezer, \& Yost, 2010). Miclea (2003, p. 266) emphasizes that EFL curriculum courses offered in English could increase the competitiveness of students willing to enter European and international labor market. They also attract more foreign students which is central to internationalization of education.

Moreover, Egypt is keen to preserve mutual interaction with the Englishspeaking world. Therefore, the idea of global participation is explicitly stated in the Egyptian National Curriculum Framework for English as a Foreign Language. The Egyptian Ministry of Education stated in the Strategic Plan for Pre-university Education Reform 2014-2030 that "every child has an equal right to receive quality education in accordance with international standards, thus allowing every child to contribute effectively to the social and economic development of the country and to compete regionally and globally" (p.2).

Education Internationalization is relatively a new and unique concept in education in general and foreign language teacher education program in particular. Nowadays, Egyptian education has been witnessing a dramatic reform. The Egyptian educational reform is not limited to the digitalization of school curricula and assessments. The reform agenda targets the current Egyptian teacher education (ETE). Nationally, the driving force behind the ETE renovation should match the domestic reform visions and remedy the drawbacks of the existing ETE. In addition, ETE renovation has to respond to the digital transformation in Egypt. However, ETE renovation should not be a mere reproduction of the existing ETE models which were designed under the influence of some outdated theories that mismatch the $21^{\text {st }}$ century teaching profession ideals. ETE renewal should keep an eye on the national requirements and the other on some outstanding international models.

Internationalization of ETE has to be one of the driving forces of educational reform in Egypt. Teacher education should cross the national 


\section{Mohamed Farrag Ahmed Badawi}

boundaries to prepare competent teachers who are able to compete peers regionally and internationally. The core component of ETE renovation should benefit from some outstanding similar teacher education curriculum in high-ranked countries. That is to say, the internationalization of the ETE should be perceived as a key tool for improving the quality of education in general and teacher education in particular. Internationalization of education is recognized as an economic commodity because it makes education tradable in the international education market. While Egypt seeks to be a regional educational center in North Africa and in the Middle East as well, the current ETE is not satisfactory. Thus, the internationalization of Egyptian education in general and ETE in particular seems to be a must. More importantly, internationalization of Egyptian education should not be at the expense of the national identity. Internationalization of education does not aim at acquiring new nationalities or identities, it is rather aiming at equipping teachers with new international competencies.

Since teachers are the product of their education programs, poor teacher preparation programs produce incompetent teachers. Betts, Andrew, and Rice (2003) argued that there is a strong relation between students' outcome gains and teacher pre-service preparation. Zein (2018, p.14) claimed that new English teacher education curricula should be extended beyond the delivery of subject content. English teacher preparation must enable prospective English teachers to face an unknown and increasingly globalized future. In this respect, the question of teacher preparation receives less attention in publications on English language teaching (Spolsky \& Sung, 2015) and much more about preparing English teachers at pre-service level of education remains unclear. Thus, investigating EFL teacher preparation is not only important but also timely in order to explore deeply teacher education. The present research project attempted to evaluate the current EFLTEC and suggest an internationalized EFLTEC. The internationalized EFLTEC seems to be an urgent course of action to guide the Egyptian reformers or policy makers. Moreover, proposing an internationalized curriculum may help the policy makers and curriculum developers with a profile on the internationalization of education which may fill the gap in EFL literature in Egypt and in the Arab world as well.

\section{Context of the problem}

Firstly, the importance of international skills and knowledge is widely accepted concern among educationalists. Human rights, environmental security, the capacity to communicate with people of diverse backgrounds are attributes that will support the current generation of university students to find out their way in the world. Hence, universities have 
revised their aims and objectives to incorporate international skills and knowledge as core graduate qualities. However, Crosling and Edwards (2008, p108) claimed that little work has been done to convert this new priority into curriculum documents and teaching practices. Consequently, teacher education or preparation programs must be reviewed and reconstructed to meet the needs of the teacher of the $21^{\text {st }}$ century (Dykes, Gilliam, Neel \& Everling, 2012, p.2).

Secondly, in a semi-structured pilot study, the researcher interviewed 26 EFL fourth year students of the English language department, Faculty of Education, October 6 University, Giza. It was easy for the researcher, as a faculty member, to meet the students and to discuss with them the key aspects of the educational reform in Egypt and the concept of internationalization of education as well. Then, the interviewees were asked to answer orally the following question: To what extent could the current EFL Teacher Preparation Program (EFLTPP) meet the requirements of the concurrent education reform in Egypt? Before leaving, the interviewees were given a questionnaire of 13 items to evaluate the extent to which the current EFL Teacher Preparation Program (EFLTPP) meet the requirements of internationalized EFL teacher education curriculum (sea Appendix 1-1).

Thirdly, the Sustainable Development Strategy of Egypt Vision 2030 (SDS) which stated that one of the challenges of Higher Education in Egypt is poor foreign language proficiency of some teachers and students. Another challenge of the current programs is the inadequacy of graduates' skills compared with labor market requirements. The skills shown by graduates of higher education institutions in relation to the labor market's requirements are insufficient, as the result of the absence of ongoing revision of the curricula so as to keep pace with labor market needs. In addition, there is a lack of funding for student activities. This raises the need for training on the requirements of different job vacancies in various fields (SDS, p.207-208).

Coupling the participants' oral responses to the pilot study questionnaire findings revealed that the current EFLTPP does not meet the key the national and international requirements for the educational reform in Egypt.

Therefore, the present research project attempted to develop an internationalized curriculum for educating EFL Egyptian secondary school teachers. Internationalizing Egyptian universities is one of the aims of SDS (SDS, p. 214). To develop the internationalized curriculum, the Sustainable Development Strategy (SDS), the National Academic 
Reference Standards (NARS), American Council on the Teaching of Foreign Language (ACTFL), National Council for Accreditation of Teacher Education (NCATE), the Standards of the Council for Accreditation of Educator Preparation CAEP, the Australian Professional Standards for Teachers (APST), Cambridge English Teaching Framework (CETF), Sustainable Development Goals (SDGs), and $21^{\text {st }}$ Century Skills were analyzed. Such carful document analysis represented the backbone of the suggested internationalized EFL teacher education curriculum.

\section{Statement of the Problem}

The current EFL Teacher Education Curriculum, October 6 University, is neither sufficient for meeting national educational reform requirements nor for coping with innovative international standards. Consequently, this research project attempted to develop an internationalized curriculum for EFL secondary school teacher education based on the integration of national and international standards.

\section{Research Questions}

The research attempted to answer the following questions:

4.1. To what extent does the current EFLTEC beneficial for EFL majors?

4.2. What are the basic features of the suggested internationalized EFLTEC?

\section{Aim of the Study}

The aim of the research was to evaluate current EFLTEC in light of the national and international standards and to develop a new Internationalized Curriculum for Egyptian secondary school EFL teachers' education.

\section{Significance of the Study}

The present research work met one of the core requirements of the current Egyptian educational reform which is teachers' education curriculum. The study could be a pioneer project as it targeted the internationalization of Egyptian EFL teachers' education curriculum. The suggested internationalized EFL teachers' education curriculum depended on two national references (NARS, and SDS 2030) and seven international references (NCATE, ACTFL CAEP, APST, CETF, SDGs, and $21^{\text {st }}$ Century Skills). The suggested internationalized EFL teachers' education curriculum could be an educational reform reference for the Egyptian policy makers. 


\section{Definitions of Terms}

\subsection{Education Internationalization}

According to Knight (2007, p. 134), Internationalization is "a multifaceted process that is integrating an international dimension into the purpose, goals, functions and delivery of higher education". Procedurally, this research defines education internationalization as a process through which national education reform may adopt or adapt some selected new international standards, competencies and guidelines to upgrade education quality and competitiveness.

\subsection{Internationalized Curriculum}

Procedurally, Internationalized Curriculum means adding some selected international standards, competencies and guidelines to strengthen the national curriculum. Internationalized Curriculum was intentionally used in this study to stress the fact that Internationalized Curriculum supports nationalization. In contrast, International Curriculum means replacing national curriculum by a new international one.

\subsection{Internationalized Curriculum for Egyptian EFL Teachers' Education} Procedurally, the Internationalized Curriculum for Egyptian EFL Teachers' Education refers to the suggested curriculum for secondary school teachers which integrates both national and some selected international requirements.

\subsection{National References}

National references refers to the selected Egyptian authorized documents related to educational reform such as NARS and SDS of Egypt Vision 2030.

\subsection{International References}

In the current study, international references refer to the selected international publications or formal documents related to teacher preparation such as NCATE, ACTFL CAEP, APST, CETF, SDGs, and $21^{\text {st }}$ Century Skills.

\subsection{Foreign Language Program Standards}

According to the American National Council for Accreditation of Teacher Education (NCATE), foreign language program standards, refer to what a foreign language teacher must know and be able to do (NCATE, 2008, P.58). 


\section{Research Delimitations}

The research findings should be realized in light of the selected integrated standards and competencies. The integrated standards and competencies were modified and restated to make good use of all the targeted references. Accordingly, not all the selected standards and competencies match all the references. Evaluation was limited to the EFL teachers' education curriculum of the Faculty of Education at October 6 university which is an identical version of that of the Faculty of Helwan University. EFL supervisors and teachers participated in the study were from Giza general Directorate of Education.

\section{Review of Literature}

Living in a global era requires internationally competent citizens. Global competency is realized as "having an open mind while actively seeking to understand cultural norms and expectations of others, leveraging this gained knowledge to interact, communicate and work effectively outside one's environment" (Hunter, White \& Godbey, 2006, p. 270). The internationalization of higher education is growing rapidly, and a large number of publications have highlighted the importance of this process (Ennew \& Greenaway 2012; Maringe \& Foskett 2013). European governments have urged universities to establish internationalization strategies and have indicated that developing such strategies is a requirement for modern academia (Lueg, 2018, p.47). Accordingly, colleges and universities tend to internationalize their curricula. Maringe (2010) identified five broad categories of internationalization strategies: 1) the recruitment of international students; 2) student and staff mobility; 3) international partnerships, including joint programmes of study; 4) international collaboration for research, entrepreneurship or development; and 5) Internationalisation of the curriculum. For Kehm and Teichler (2007), research on internationalization in higher education demonstrates the growing importance of internationalization as a priority issue (p. 262). Altbach and Knight (2007) argued that via internationalization "... academe has regained its international scope and direction ... Internationalism will remain a central force in higher education, though its contours are unclear" (p. 303).

The internationalization of higher education is realized as the process of integrating an international or intercultural or global dimension within the targeted national education system. Knight (2002) considered internationalization of higher education, as the integration of international, intercultural and global dimensions within the functions of education. Similarly, Lee, \& Cai, (2018) stated that internationalization of 
higher education is to include international, intercultural, or global components into the delivery of postsecondary education has drawn increasing attention in the last two decades. According to Knight (2008) internationalization means "integrating an international, intercultural or global dimension into the purpose, functions or delivery of postsecondary education" (p. 11). This definition is one of commonly accepted definitions. looked at Internationalization as "the intentional process of integrating an international, intercultural or global dimension into the purpose, functions and delivery of post-secondary education, in order to enhance the quality of education and research for all students and staff, and to make a meaningful contribution to society" (De Wit, Hunter, Howard \& Egron-Polak, 2015, p. 281). In addition, Leask (2015, p.61) mentioned that internationalization of the curriculum means "the incorporation of international, inter-cultural, and/or global dimensions into the content of the curriculum as well as the learning outcomes, assessment tasks, teaching methods and support services of a program of study." Green and Schoenberg (2006, p. iii) stated that internationalization of curriculum is the "most important strategy institutions can use to ensure that all students acquire the knowledge, skills, and attitudes they will need as citizens and workers in a rapidly changing and globalized world." The kernel point is that internationalization of education or rather internationalization of curriculum is the catalyst of education reform in the countries welling to realize education competitiveness and accreditation recognition. However, there is scarce discussion of how specifically university courses and curricular could exemplify an international component (Jones \& Killick, 2013; Leask, 2013).

While many researchers advocate Internationalization of education, others oppose such trend. Advocates of internationalization of education mention that the key benefit of internationalization of education is preparing graduates who are internationally knowledgeable and cross culturally sensitive (Tahira \& Masha 2015, p. 197). It is internationalization of education that allows students understand the connections between the local environment in which they live, and the global environment (Vainio-Mattila, 2009). The positive aspects of internationalization include improved academic quality, internationally oriented students and staff, and national and international citizenship for students and staff from underdeveloped countries (Tahira \& Masha, 2015, p. 197). For Kreber (2009), internationalization develops ethical commitment to allow students to examine their implicit and explicit 


\section{Mohamed Farrag Ahmed Badawi}

beliefs and develop a sense of responsibility and civic engagement. In light of such benefits, Hudzik (2015) called for "comprehensive internationalization" that can infuse and integrate international, global, and comparative content and perspective throughout the teaching, research, and service missions of higher education. This integration should be intentional institutional commitment. Such extreme view concerning comprehensive internationalization evokes opponents to resist internationalization of education.

On the other hand, opponents of internationalization of education believe that the loss of cultural or national identity, homogenization of international curriculum and "brain drain" are threats that are inherent in the internationalization of higher education (Eldik, 2011). Moreover, Knight (2007) argued that the loss of cultural identity is definitely the most significant risk factor attached to the process of internationalization. Altbach and Knight (2007) stated that education internationalization colonization includes internationalization of curriculum, programs, academic staff and the students.

To narrow the gap between internationalization advocates and opponents, Beelen and Jones (2015) suggested a new type of education internalization which is "internationalization at home" where students remain on domestic learning environments but are educated on international and intercultural elements in their formal and informal curriculum. According to Beelen and Jones (2015, p.69) "Internationalization at Home is the purposeful integration of international and intercultural dimensions into the formal and informal curriculum for all students, within domestic learning environments". Accordingly, the current study is after partial internationalization of education which infuses some international dimensions to the national curriculum.

As mentioned before, the Internationalisation of the curriculum refers to the integration of international, intercultural and global dimensions into the content of the curriculum, learning outcomes, assessment tasks, teaching methods and support services of a given study program. For Leask (2001, p.140-142), the internationalized curricula should prepare graduates for professional practices in the international environment determine course content and delivery. Internationalized curricula should be recognized by international accrediting bodies. Internationalized curricula should lead to joint or double study that combines international and cross-cultural studies components with professional degrees in international and studies and leads to conferral of a double or joint degree. Curricula with an international courses include international studies and subjects as a major or sub-major. Internationalized curricula 
broaden traditional course content to include specific reference to contemporary international dimensions. Curricula in foreign languages should identify cross-cultural communication content and linguistics that explicitly address communication skills.

Yamada (2018) evaluated how effectively an English as a Foreign Language (EFL) training program helps Japanese EFL teachers prepare for their future career. Interviews and surveys were used to collect data. Interviews were first conducted with Japanese teacher trainees enrolled in the program to identify concerns related to their EFL learning and teacher training. Since the interviews revealed potential areas for a new direction in the EFL curricula, surveys were later conducted to focus on the teacher trainees' perceptions of Japan's diversity Japan's diversity. About $74 \%$ of the students felt they learned about people from diverse cultural and linguistic backgrounds through their English classes, and about 59\% said that the materials were relevant to their daily experiences.

Molstad and Karseth (2016) investigated the fundamental distinctions between content based curricula and learning outcomes based curricula and examined how learning outcomes are incorporated into written national curricula for compulsory schooling in Norway and Finland. They found that learning outcomes are integrated in both countries. The Norwegian approach neglects an essential distinction between matter and meaning by employing an outcome-oriented curriculum. Accordingly, teacher preparation programs should be renewed to match the current shift.

Ping (2015) evaluated a preservice English teacher education in a Chinese university context. To evaluate the program, questionnaires and semistructured interviews were used. The questionnaires were completed by 300 participants, 200 of whom were then randomly chosen as interviewees. The findings revealed that the program lacked opportunities for practice. In addition, as a good point, the student-teachers were allowed to decide on the content of some courses.

In 2006, Turkey changed EFL teacher preparation program to keep pace with social, economic, political, and technologic advancements in the world. The new Turkish EFL teacher preparation program includes of a number of obligatory courses with a few elective ones. The program components contain general knowledge, linguistic competence, pedagogical competence, and teaching practice. The program essentially puts emphasis on teaching methodology and the teaching practice component. In this new program, the total number of hours the student teacher spends in the classroom is 175 , out of which 143 hours are 
apportioned to theory-based deduction, while the remaining 32 hours are scheduled for teaching practice, special teaching methods, and computer skills. More importantly, the pedagogical dimension was added to the literature course, thereby changing its name into Literature and Language Teaching (Goktepe, 2015).

Nguyen (2013) examined the curricula of the English teacher Education in Australia and Vietnam. One university represented each country. Specifically, it examines the structures of the two curricula, compares and contrasts them, and examines how the development of the curricula was shaped by distinct contextual factors. Sources of data include relevant literature, policy and curriculum documents, and interviews with curriculum developers from the two universities. Data analysis revealed variation across and within the two curricula in terms of structure and content. Findings also revealed specific contextual factors that influenced the development of the curricula.

Urbanovic and Wilkins (2013) anticipated stakeholders' opinions on the benefits and disadvantages of education Internationalisation in Lithuania. It was revealed that Internationalisation can present both opportunities and challenges to small states. However, the overwhelming consensus among the range of stakeholders who participated in this study was that the benefits of Internationalisation far outweigh the threats and disadvantages. Internationalisation promotes cultural integration and harmony, improves the quality of education and research, and improves country and institutional reputations internationally.

Abaszadeh (2012) conducted a study comparing teachers' and teacher trainers' views about essential elements of teachers' knowledge base and typical problems faced by Iranian English teachers. While trainers' point of view indicated that language proficiency and communication skill, teaching skills and technicalities of the job, knowledge of the learner, self-awareness, and self-evaluation were necessary for EF teachers, the teachers believed that language proficiency and classroom language, knowledge of theories of second language teaching and learning, teaching skills, knowledge of target culture and its teaching, and assessment and error correction techniques were essential for teaching EF. Han (2010) used a questionnaire survey to collect data to analyze the present situation of pre-service TEFL education for English teaching and its influence on the teaching in the future. Results revealed that the strong points were more than the weak points of the BA pre-service English program in Chinese universities.

Coskun \& Daloglu (2010) investigated Turkish teacher education programs to reveal the pre-service English teacher education program 
components that are in need of improvement or maintenance both from teachers' and students' perspectives. The data collected by means of questionnaires and interviews showed that although participating teachers and student teachers have similar views about some program components, they hold different ideas about the balance among linguistic and pedagogic competences in the program. While teachers believe that the program does not suffice to improve student teachers' linguistic competence, student teachers think that the pedagogic side of the program needs to be improved.

Chong and Cheah (2009) evaluated a pre-service TEFL teacher program in Singapore. Based on data collected from final year student teachers, it was concluded that while the framework of values, skills, and knowledge provided the student-teachers with maxims of teaching and learning, they were far from practical implementation in the field practice. The researchers recommended that the would-be teachers should see their initial teacher education as a start of continuing professional development. They need to learn from experience through reflection.

Zou (2009) tried to find out the causes of the poor quality of a BA English education program and make suggestions for future reform. Through semi-structured interviews and other techniques, he concluded that the teachers lack academic knowledge, an ability to evaluate students and conduct effective teaching. In a similar study, Peacock (2009) evaluated EFL teacher-training program of the City University of Hong Kong. Evaluation procedure focused on program strengths and weaknesses and how far the program meets the needs of students. The researcher evaluated the TEFL program- in light of the data collected from students, teachers, and alumni through interviews, questionnaires, essays and analysis of program materials. The program had many strong points, including the teaching of pedagogic skills and promoting reflection and self-evaluation, but also inadequacies. It should increase the amount of Practicum and increase input in certain areas such as knowledge of teaching, local sociocultural context and classroom management.

Based on the insights gained from the review of the pertinent literature, it could be concluded that questionnaires and interviews were the common tools for evaluating teacher preparation programs. Accordingly, the study benefited from coupling the techniques to evaluate the current EFL teacher curriculum targeted by the present study. While no signal research of the available previous studies used the 
mixed approach that mixes both quantitative and qualitative approaches, the study attempted to make good use of the mixed approach as a scientific research tool. Similarly, no previous research utilized document analysis method as a form of qualitative research. The content subject/language competency was the focal point of the previous research and the same for this study. All the evaluated programs showed more weak points than strong ones. The majority of the findings of the previous research go in line with the findings resulted from evaluating the current EFLTEC. More importantly, whereas program evaluation was just the main aim of the previous research, the current study evaluated the targeted program and developed a new curriculum based on both national and international standards. The current research project applied document analysis method which in Bowen's (2009, p.28) words "a form of qualitative research in which documents are interpreted by the researcher to give voice and meaning around an assessment topic".

\section{Method}

\subsection{Research Participants}

The participants in the research project were EFL fourth-year students enrolled in the English Language Teaching Department of the Faculty of Education at October 6 University, Egypt. All EFL fourth-year students 123 were invited to participate in the study. Responded students were 96 (78\%) participants. Age, gender and EFL proficiency level were disregarded.

\subsection{Research Tools and Material}

\subsubsection{EFL Majors' Interview}

The interviewees (26 EFL majors) were asked to answer orally the following question: To what extent could the current EFL Teacher Preparation Program (EFLTPP) meet the requirements of the concurrent education reform in Egypt? This measure was necessary for the pilot study to gain more insights to assure the deficiency of that the current EFL Teacher Preparation Program (EFLTPP).

\subsubsection{EFL Majors' Pilot Questionnaire (1-1)}

After finishing of the interview session, the participants were given a questionnaire of 13 items targeting the extent to which the current EFL Teacher Preparation Program (EFLTPP) meet the requirements of internationalized EFL teacher education curriculum (Appendix 1-1). Coupling the participants' oral responses to the questionnaire findings revealed that the current EFLTPP does not meet the key the national and international requirements for the educational reform in Egypt. This measure was a part of the pilot study. 
10.2.3. EFL Majors' Main Questionnaire (1-2)

As a part of the main study, a questionnaire of 10 items targeting the extent to which the current EFL Teacher Preparation Program (EFLTPP) meet the requirements of internationalized EFL teacher education curriculum (sea Appendix 1-2). The questionnaire covered ten competencies. Namely, English language communication, teaching EFL skills, digital instruction, digital assessment, national labor market requirements, international labor market requirements, practicing universal education, special needs instruction, refugees' instruction learners and self- learning skills. Some items were taken from the pilot study questionnaire (Appendix 1-1). The questionnaire was sent 7 EFL experts and proved valid. Correlation between the questionnaire (sea Appendix 1-2) and the pilot study questionnaire (sea Appendix 1-1) was $r$ $=0.68$.

\subsubsection{EFL Experts' Standards Rating Sheet (2-1)}

The EFL Experts' Standards Rating Sheet was developed to evaluate the suggested internationalized Standards in terms of the Statement, Feasibility, Relevancy, Importance and Sufficiency. The International Standards were rated using a three-grade scale namely; V. Good, Good and Poor. EFL experts (9) participated in the discussions guided by Delphi and Focus Group techniques admitted the validity of the Rating Sheet. Using split technique indicated that the value of $r=0.91$. Accordingly, the Rating Sheet was considered reliable (Appendix 2-1).

\subsubsection{EFL Experts' ILOs Rating Sheet (2-2)}

The EFL Experts' ILOs Rating Sheet was developed to evaluate the suggested internationalized ILOs in terms of their relevancy, importance and sufficiency. The International ILOs were rated using a three-grade scale namely; V. Good, Good and Poor. Nine EFL experts participated in the discussions guided by Delphi and Focus Group techniques admitted the validity of the Rating Sheet. Using split technique revealed that the value of $r=0.92$. Accordingly, the Rating Sheet was considered reliable (sea Appendix 2-2).

\subsubsection{EFL Experts' Courses Rating Sheet (2-3)}

The EFL Experts' Courses Rating Sheet was developed to evaluate the suggested internationalized Courses in terms of their relevancy, importance, sufficiency and distribution. The International ILOs were rated using a three-grade scale namely; V. Good, Good and Poor. Nine EFL experts participated in the discussions guided by Delphi and Focus Group techniques admitted the validity of the Rating Sheet. 
Using split technique revealed that the value of $r=0.94$. Accordingly, the Rating Sheet was considered reliable (sea Appendix 2-3).

10.2.7. EFL Experts' Curriculum Rating Sheet (2-4)

The EFL Experts' Courses Rating Sheet was developed to evaluate the suggested internationalized Curriculum in terms of the National and International requirements. The Internationalized Curriculum was rated using a three-grade scale namely; V. Good, Good and Poor. Nine EFL experts participated in the discussions guided by Delphi and Focus Group techniques admitted the validity of the Rating Sheet. Using split-half technique revealed that the value of $r=0.96$. Thus, the Rating Sheet was considered reliable (sea Appendix 2-4).

10.2.8. Documents of Reference Material

Document analysis included 2 national documents (Sustainable Development Strategy SDS and National Academic Reference Standards NARS) and 7 international documents (National Council for Accreditation of Teacher Education NCATE, American Council on the Teaching of Foreign Language ACTFL, Standards of the Council for Accreditation of Educator Preparation CAEP, the Australian Professional Standards for Teachers APST, Cambridge English Teaching Framework CETF, Sustainable Development Goals SDGs and $21^{\text {st }}$ Century Skills).

\subsection{Research Approach}

Atmowardoyo (2018, p.197) stated that "A careless procedure a researcher uses will result invalid data, which in turn will result unreliable and probably harmful findings and recommendations." Research method is a systematic procedure a researcher uses to solve the research problem or to answer the research questions. Research method controls research design, data collection, and data analysis. Accordingly, the present research project used the mixed approach, that is, the mixture of both quantitative and qualitative approaches. Document analysis method is a form of qualitative research in which documents are interpreted by the researcher to give voice and meaning around an assessment topic (Bowen, 2009). Document analysis is a systematic procedure for reviewing or evaluating printed and electronic documents. Like other analytical methods in qualitative research, document analysis requires that data be examined and interpreted in order to elicit meaning, gain understanding, and develop empirical knowledge (Corbin \& Strauss, 2008; Rapley, 2007). 


\subsection{Procedures}

After the study tools were developed and the required documents were collected, the main study procedures started with collecting the targeted quantitative data using EFL majors' questionnaires. Then, document analysis included 2 national documents (Sustainable Development Strategy SDS and National Academic Reference Standards NARS) and 7 international documents (National Council for Accreditation of Teacher Education NCATE, American Council on the Teaching of Foreign Language ACTFL, Standards of the Council for Accreditation of Educator Preparation CAEP, the Australian Professional Standards for Teachers APST, Cambridge English Teaching Framework CETF, Sustainable Development Goals SDGs and $21^{\text {st }}$ Century Skills). Since document analysis represents the backbone of the suggested internationalized EFL teacher education curriculum, relevant standards and guidelines were first elicited from the targeted documents. While the first draft of the Selected National Standards involved 14 standards (sea Appendix 12-1), the first version of the Selected International Standards contained 44 standards (sea Appendix 12-2). Hence, the Integrated National and International Standards were 58 (sea Appendix 12-3). Avoiding repetition and focusing on compatibility, the 58 integrated standards were reduced to be 24 standards. Another attempt was made to condense the selected compatible 24 standards. While some specific standards and guidelines were merged to be somewhat comprehensible to match standards formulation, very specific standards were translated to ILOs and course topics. The final Internationalized Standards list included 7 standards (sea Appendix 12-5). Each standard was given a percentage weight as follows: Content Subject Knowledge and Skills (60\%) Instructional Pedagogical Knowledge and Skills (10\%) Psychological Pedagogical Knowledge (5\%) Digitalized Knowledge and Skills (5\%) Universal Educational Background Knowledge (5\%) Cultural Knowledge (5\%) and Teaching Practicum (10\%). These percentages were suggested to be applicable to a program of 140 Credits. Finally, the Internationalized Standards were sent to EFL experts to be evaluated (sea Appendix 12-5).

In light of the Internationalized Standards, 70 courses were suggested covering English Linguistics, World Literature, Language Skills, Curricula, EFL Instruction, EFL Assessment, Psychology, Mental Health, Educational Technology, Digital Learning, Educational Management, Universal Education, National Culture, International Culture, In-Campus Teaching Practice and In-School Teaching Practice (sea Appendix 12- 
15). Curricula courses were divided into 8 study levels along 4 academic years. Introductory and foundation courses were placed in the first and second levels. More specialized and practical courses were placed in higher levels. Guided by the suggested courses, 229 ILOs were stated. The stated ILOs covered 5 domains. Eighty ILOs were devoted to knowledge domain (sea Appendix 12-10). Seventy-nine ILOs were devoted to intellectual domain (sea Appendix 12-11). Sixty ILOs were devoted to professional domain (sea Appendix 12-12). Five ILOs were devoted to general domain (sea Appendix 12-13). Finally, five ILOs were devoted to international domain (sea Appendix 12-14).

Again, the results of the document analysis and the developed Internationalized Curriculum for Egyptian Secondary School EFL Teachers' Education were quantitatively treated using EFL experts' questionnaires. EFL experts' evaluation proved the suggested Internationalized Curriculum for Egyptian Secondary School EFL Teachers' Education meets the national and international requirements. EFL Experts' evaluation ratings and EFL majors' responses were tabulated and statistically interpreted. It should be noted that no attempt was made to experiment the suggested Internationalized Curriculum because of the official routine and time constrains since the experimentation needs four years. All the procedures were accomplished by the end of the $2^{\text {nd }}$ term of the academic year 2017-2018.

\section{Research Results}

\subsection{Results of EFL Majors' Total Evaluation of the Current EFLTEC} Table 1: EFL Majors' Item Evaluation of the Current EFLTEC

\begin{tabular}{llllll}
\hline $\mathrm{N}$ & Items & \multicolumn{3}{l}{ Response Frequency } \\
$\mathrm{o}$ & Agree & Uncertain & Disagree \\
& n. $\%$ & n. $\%$ & n. $\%$
\end{tabular}

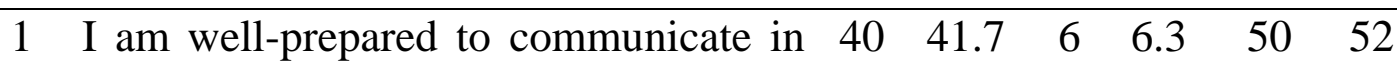
English language.

$\begin{array}{llllllll}2 & \text { I am well-prepared to teach EFL skills } & 32 & 33.3 & 8 & 8.3 & 56 & 58.3\end{array}$ effectively.

$\begin{array}{llllllll}3 & \text { I am well-prepared to instruct digitally. } & 31 & 32.3 & 5 & 5.2 & 60 & 62.5\end{array}$

$\begin{array}{llllllll}4 & \text { I } \text { am well-prepared to assess digitally } & 8 & 8.3 & 3 & 3.1 & 85 & 88.5\end{array}$ learners' ILOs.

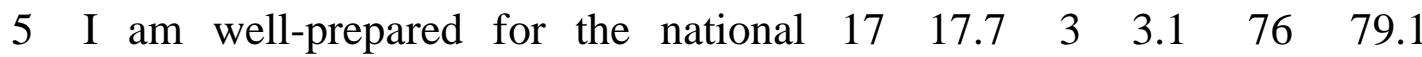
labor market.

6 I am well-prepared to for the $\begin{array}{lllllll}15 & 15.6 & 1 & 12.5 & 69 & 71.9\end{array}$ international labor market.

$\begin{array}{lllllllll}7 & \text { I } & \text { am well-prepared to practice the } & 8 & 8.3 & 9 & 9.4 & 79 & 82.3\end{array}$ universal education. 


\begin{tabular}{|c|c|c|c|c|c|c|c|}
\hline \multicolumn{8}{|c|}{$\begin{array}{l}\text { The Development of a Suggested Internationalized } \\
\text { Prospective EFL Teachers }\end{array}$} \\
\hline \multirow{3}{*}{$\begin{array}{l}\Gamma \\
0\end{array}$} & \multirow[t]{3}{*}{ Items } & \multicolumn{6}{|c|}{ Response Frequency } \\
\hline & & \multicolumn{2}{|c|}{ Agree } & \multicolumn{2}{|c|}{ Uncertain } & \multicolumn{2}{|c|}{ Disagree } \\
\hline & & $\mathrm{n}$. & $\%$ & $\mathrm{n}$. & $\%$ & $\mathrm{n}$. & $\%$ \\
\hline 8 & $\begin{array}{l}\text { I am well-prepared to instruct special } \\
\text { needs learners. }\end{array}$ & 15 & 15.6 & 0 & 0 & 81 & 84.3 \\
\hline 9 & $\begin{array}{l}\text { I am well-prepared to instruct refugee } \\
\text { learners. }\end{array}$ & 12 & 12.5 & 4 & 4.2 & 80 & 83.3 \\
\hline 1 & $\begin{array}{l}\text { I am well-prepared to instruct learners } \\
\text { how to learn. }\end{array}$ & 21 & 21.9 & 2 & 2.1 & 73 & 76 \\
\hline \multicolumn{2}{|c|}{ Total $($ Max.96 $\times 10=960)$} & $\begin{array}{l}19 \\
9\end{array}$ & $\begin{array}{l}20.7 \\
\%\end{array}$ & $\begin{array}{l}5 \\
2\end{array}$ & $\begin{array}{l}5.4 \\
\%\end{array}$ & $\begin{array}{l}70 \\
9\end{array}$ & $\begin{array}{l}73.9 \\
\%\end{array}$ \\
\hline
\end{tabular}

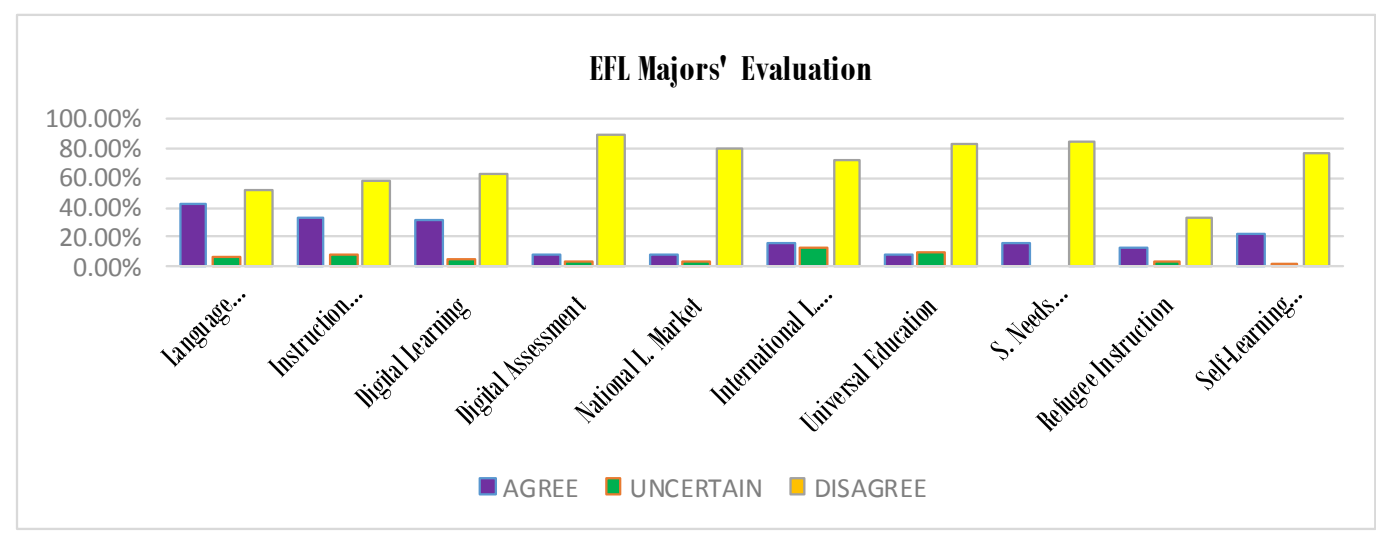

\section{Chart 1: EFL Majors' Item Evaluation of the Current EFLTEC}

Table 1 and Chart 1 display that while agree frequency percentage of the first item was (41.7\%), disagree frequency percentage was (52\%). As for the second item, EFL Majors' responses indicated that agree frequency percentage was $(33.3 \%)$ and disagree frequency percentage was $(58.3 \%)$. As displayed, EFL Majors' responses to the third item revealed that agree frequency percentage was (32.3\%) and disagree frequency percentage was (62.5\%). As for the fourth item, EFL Majors' responses indicated that agree frequency percentage was $(8.3 \%)$ and disagree frequency percentage was $(88.5 \%)$. The fifth item showed that EFL Majors' agree frequency percentage was (7.7\%) and disagree frequency percentage was $(79.1 \%)$. As for the sixth item, EFL Majors' responses indicated that agree frequency percentage was $(15.6 \%)$ and disagree frequency percentage was (71.9\%). Similarly, the seventh revealed that EFL Majors' agree frequency percentage was $(8.3 \%)$ and disagree frequency percentage was $(82.3 \%)$. As for the eighth item, EFL Majors' responses indicated that agree frequency percentage was (15.6\%) and disagree frequency percentage was $(84.3 \%)$. The ninth item showed that EFL Majors' agree frequency percentage was (12.5\%) and disagree 


\section{Mohamed Farrag Ahmed Badawi}

frequency percentage was (83.3\%). Finally, the tenth item demonstrates that EFL Majors' agree frequency percentage was (21.9\%) and disagree frequency percentage was $(76 \%)$. Generally, while disagree percentages are ranging from $(52 \%)$ to $(88.5 \%)$, the agree percentages are between $(8.3 \%)$ and $(41.7 \%)$. Accordingly, it could be concluded that the current curriculum is ineffective in terms of the ten questionnaire items.

Table 2: EFL Majors' Total Evaluation of the Current EFLTEC

\begin{tabular}{lll}
\hline Response & \multicolumn{2}{l}{ Total Frequency and Percentages } \\
& Number & Percentage \\
\hline Agree & 199 & $20.7 \%$ \\
Uncertain & 52 & $5.4 \%$ \\
Disagree & 709 & $73.9 \%$ \\
\hline Total $($ Max. $96 \times 10=51)$ & 960 & $100 \%$ \\
\hline
\end{tabular}

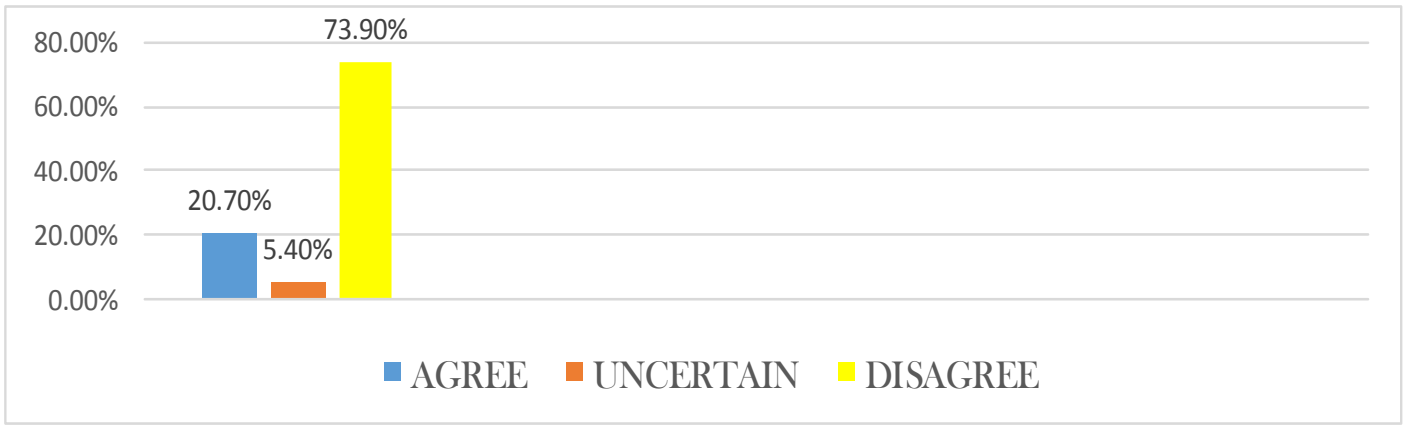

\section{Chart 2: EFL Majors' Total Evaluation of the Current EFLTEC}

Table 2 and Chart 2 show that most of EFL majors (73.9\%) were not satisfied with the effectiveness of the curriculum of the current preparation program in terms of the ten competencies underlying the questionnaire ten items. While the percentage of those who were satisfied with the current curriculum was $(20.7 \%)$, the percentage of those who were uncertain was $(5.4 \%)$. Based on these ratings, it could be concluded that the current curriculum is ineffective in terms of EFL ratings.

Coupling the results shown in Table 1 and Chart 1 to those displayed in Table 2, the answer of the first question: To what extent does the current EFLTEC satisfy EFL majors? The answer is that most of EFL majors $(73.9 \%)$ were not satisfied with the effectiveness of the curriculum of the current preparation program in terms of the ten competencies underlying the questionnaire ten items. 


\subsection{Results of Document Analysis}

First Document: Sustainable Development Strategy (SDS): Egypt Strategic Vision 2030

According to the SDS, technology represent the backbone of reforming education however Egypt is still far below the level of such developments (SDS, p. 171). In addition, quality and accreditation rules should "conform to global standards" and education has to "empower the learner with the requirements and skills of the $21^{\text {st }}$ Century". Moreover, "curricula should be developed to cope with global developments and information updates and take into consideration the age of the learner and his biological and psychological needs to build up personality". Education should "contribute to the development of a proud, creative, responsible, and competitive citizen who accepts diversity and differences, and is proud of his country's history, and who is eager to build its future and able to compete with regional and international entities (SDS, p. 174).

In other words, according to the first objective of the SDS, educational reform in higher education should consider global accreditation and quality standards. The National Education Quality Assurance and Accreditation standards must be modified to comply with global standards. The second objective is responsible for providing high quality educational services for all students. It is responsible for integrating people with minor disabilities into schools and looking after talented and distinguished learners who need a supportive environment. The third objective is related to competitiveness tied to quality and availability of education in Egypt compared with other countries. This implies activating the dynamic relationship between the educational process and the labor market requirements through graduating students that are able to take hold of market opportunities (SDS, p.174-204). Moreover, university education requires much development in order to cope with the needs of the job market and produce graduates capable of facing competition nationally and internationally (SDS, p.172). SDS suggests some key elements for developing new programs to prepare teachers and qualify them to obtain technological qualifications to cope with the requirements of this era (SDS, p.184). Improving educational system quality to match international systems, effective technological and electronic forms for presenting knowledge and scientific research are required (SDS, p.204). In addition to the previously mentioned features, more relevant details are mentioned in the SDS document (sea Appendix: 3). 
Based on the above mentioned SDS educational features, five specific standards could be elicited to be included in the final list of the internationalized EFLTEC. Accordingly, education should care about:

1. International accreditation and quality standards.

2. Learners with minor disabilities and talented learners.

3. Competing nationally and internationally.

4. Meeting the needs of the national and international labor market.

5. Technological and electronic facilities.

Second Document: National Academic Reference Standards (NARS)

The current 51 NARS educational standards and ILOs are (Appendix: 4) are subject to be modified to comply with global standards (SDS p.174), yet some of them are expected to remain in the modified NARS version. According to NARS, educational and instructional component should be $(15-25 \%)$, technology (5-7\%), practicum (12-18\%), cultural (3-7\%), and content knowledge (43-57\%). Apparently, the problem of NARS is related the imbalanced weight that is given to each domain. In light the mentioned NARS and those stated in Appendix (4) nine specific standards could be selected to be included in the final list of the internationalized EFLTEC. Accordingly, faculties of education should care about:

1. Cultural domain.

2. Pedagogical skills.

3. Technology based teaching, and learning.

4. Content subjects.

5. Psychological domain.

6. Research skills.

7. Community service.

8. Quality education.

9. Assessment of ILOs.

\section{Third Document: NCATE Standards}

According to the American National Council for Accreditation of Teacher Education (NCATE), foreign language program standards, refer to what a foreign language teacher must know and be able to do. Foreign language teachers (FL) teachers demonstrate a high level of proficiency in the target language and seek opportunities to develop their proficiency. FL teachers understand the linguistic elements and changing nature of the target language. They recognize the similarities and differences between the target language and other languages. They modify foreign culture aspects in foreign language teaching and learning. FL teachers use literary and cultural texts to analyze the perspectives of target cultures over time. They understand language acquisition at various developmental levels and use this knowledge to create supportive and meaningful classroom 
environments. FL teachers provide a range of learning opportunities to meet the needs of language learners' diversity. Teachers understand the goal areas and standards of Foreign Language Learning in the $21^{\text {st }}$ Century and integrate them into planning and instruction. They use standards and curricular goals to evaluate, select, adapt, and design instructional materials. They conduct valid formative assessments to assess student performance. They report the results of the assessment to all stakeholders and adjust instruction accordingly. Foreign Language teachers engage in professional development opportunities and reflect on their practice. They know the value of foreign language learning and understand their roles as advocates for language learning (NCATE, 2008, p.58).

Based on the above mentioned NCATE standards and the detailed explanation reported in Appendix (5), eight foreign language program standards could be selected to be included in the final version of the internationalized EFLTEC as follows:

1. Have a high level of proficiency in the target language.

2. Analyze and integrate the target cultures cultural into instructional practices.

3. Apply language acquisition theories.

4. Provide learning opportunities to meet the needs of diverse language learners.

5. Care about Language Learning in the 21 st Century.

6. Conduct multiple ongoing assessments to measure student performance.

7. Engage in professional development opportunities and reflect on their practice.

8. Value foreign language learning.

Fourth Document: ACTFL Standards

The American Council on the Teaching of Foreign Language (ACTFL) specifies six standards for foreign language teacher preparation: Language proficiency: Interpersonal, Interpretive, and Presentational. Cultures, Linguistics, Literatures, and Concepts from other Disciplines; Language Acquisition Theories and Knowledge of Students and Their Needs; Integration of Standards in Planning, Classroom Practice, and Use of Instructional Resources; Assessment of Languages and Cultures Impact on Student Learning; and Professional Development, Advocacy, and Ethics (p.2). Based on ACTFL and the detailed explanation in Appendix (6), six foreign language program standards were adopted to be included in the final version of the internationalized EFLTEC as follows: 
1. Target foreign language proficiency.

2. Cultures, linguistics, literatures, and concepts from other disciplines

3. Language acquisition theories and knowledge of students and their needs

4. Integration of standards in planning, practicing, and use of instructional resources

5. Assessment of languages and cultures.

6. Professional development, advocacy and ethics.

Fifth Document: CAEP Standards

According to the Council for Accreditation of Educator Preparation (CAEP), preparing foreign language teachers should meet the following five standards: Content and Pedagogical Knowledge; Clinical Partnerships and Practice; Candidate Quality, Recruitment, and Selectivity; Program Impact; and Provider Quality Assurance and Continuous Improvement (pp.1-3). Based on CAEP and the detailed explanation in Appendix (7), five standards for foreign language teacher were adopted to be included in the final version of the internationalized EFLTEC as follows:

1. Content and Pedagogical Knowledge.

2. Clinical Partnerships and Practice.

3. Candidate Quality, Recruitment, and Selectivity.

4. Program Impact.

5. Provider Quality Assurance and Continuous Improvement Sixth Document: Australian Professional Standards for Teachers (APST) According to the Australian Professional Standards for Teachers (APST), preparing teachers should meet the following seven standards: Know student learnability; Know the content subject and how to teach it; Plan effective teaching and learning; Create supportive and safe learning environments; Assess student learning; Care about professional learning; and Cooperate professionally with peers, parents and the community (p.4). Based on APST and the detailed explanation in Appendix (8), seven standards for foreign language teacher were adopted to be included in the final version of the internationalized EFLTEC as follows:

1. Know student learnability.

2. Know the content subject and how to teach it.

3. Plan effective teaching and learning.

4. Create supportive and safe learning environments.

5. Assess student learning.

6. Care about professional learning.

7. Cooperate professionally with peers, parents and the community. 
Seventh Document: Cambridge English Teaching Framework (CETF) Cambridge English Teaching Framework (CETF) suggests five standards for teaching English language: Learning and the learner; Teaching, learning and assessment; Language ability; Language knowledge and awareness; and Professional development and values (pp.3-4). Based on CETF and the detailed explanation in Appendix (9), five standards for EFL teacher were reconsidered in the final version of the internationalized EFLTEC as follows:

1. Learning and teaching.

2. Learning and assessment.

3. Language ability.

4. Language knowledge and awareness.

5. Professional development and values.

Eighth Document: 21st Century Skills for Students/Teachers

Educational reform should recognize the $21^{\text {st }}$ Century Skills for Students/Teachers. The basic skills are: Communication and collaboration, Collaborate with Others and Critical thinking, Creativity and innovation and problem solving. In addition, there are some features of education in $21^{\text {st }}$ century: Leadership and responsibility, productivity and accountability, social and cross-cultural skills, $21^{\text {st }}$ Century assessment, problem-based learning, project-based Learning, game-based learning, technological literacy, media literacy, visual literacy, environmental literacy, health literacy, financial literacy, global awareness, civic literacy, information literacy, (pp. 2-12). In addition to the previously mentioned skills, there are further details in Appendix (10). Practically, not all the $21^{\text {st }}$ Century skills could be recognized. Recognition was given to the most relevant 9 skills:

1. Communication and collaboration.

2. Collaborate with Others.

3. Critical thinking.

4. Creativity.

5. Leadership and responsibility.

6. Social and cross-cultural skills.

7. Technological literacy.

8. Environmental literacy.

9. Global awareness.

Ninth Document: Sustainable Development Goals (SDGs)

Sustainable Development Goals (SDGs) involves 17 goals: No Poverty, Zero Hunger, Good Health and Well-Being, Quality Education, Gender Equality, Clean Water and Sanitation, Affordable and Clean Energy, 


\section{Mohamed Farrag Ahmed Badawi}

Decent Work and Economic Growth, Industry, Innovation and Infrastructure, Reduced Inequalities, Sustainable Cities and Communities, Responsible Consumption and Production, Climate Action, Life below Water, Protect Life on Land, Peace, Justice and Strong Institutions, and Partnerships for the Goals (p.6). Seemingly some of these goals could be realized as guidelines of education reform. In light of the mentioned goals and their relevant details shown in Appendix (11), recognition was given to the goals that are intrinsically relevant education. The following four goals were selected:

1. Quality education.

2. Gender Equality.

3. Environmental Protection.

4. Peace and Justice

Based on the analysis of the previous national and international documents, 14 national standards (Appendix 12-1) and 44 international standards (Appendix 12-2) were stated. The Integrated National and International Standards were 58 (Appendix 12-3). Omitting repeated standards resulted in reducing the 58 integrated standards to be 24 standards (Appendix 12-4). Merging some standards and converting others to ILOs shortened the 24 standards to be 7 standards (Appendix 12-5).

Table 3: Internationalized Standards Compatibility Matrix

\begin{tabular}{|c|c|c|c|c|c|c|c|c|c|c|}
\hline \multirow[t]{2}{*}{ No } & \multirow{2}{*}{$\begin{array}{l}\text { Internationalized } \\
\text { Standards }\end{array}$} & \multicolumn{9}{|c|}{ Referenced Standards } \\
\hline & & $\begin{array}{l}\text { SD } \\
\text { S }\end{array}$ & $\begin{array}{l}\text { NA } \\
\text { RS }\end{array}$ & $\begin{array}{l}\text { NEC } \\
\text { ATE }\end{array}$ & $\begin{array}{l}\text { ACT } \\
\text { FL }\end{array}$ & $\begin{array}{l}\mathbf{C E} \\
\mathbf{A P}\end{array}$ & $\begin{array}{l}\text { AP } \\
\text { ST }\end{array}$ & $\begin{array}{l}\text { CE } \\
\text { TF }\end{array}$ & $\begin{array}{l}2 \\
1^{\text {st }}\end{array}$ & $\begin{array}{l}\text { SD } \\
\text { Gs }\end{array}$ \\
\hline 1 & $\begin{array}{l}\text { International Accreditation } \\
\text { Standards. }\end{array}$ & $\sqrt{ }$ & $\sqrt{ }$ & $x$ & $x$ & $x$ & $x$ & $x$ & $x$ & $\sqrt{ }$ \\
\hline 2 & $\begin{array}{l}\text { Competing Nationally and } \\
\text { Internationally. }\end{array}$ & $\sqrt{ }$ & $x$ & $x$ & $x$ & $x$ & $x$ & $x$ & $x$ & $x$ \\
\hline 3 & $\begin{array}{l}\text { National and International } \\
\text { Labor Market. }\end{array}$ & $\sqrt{ }$ & $x$ & $x$ & $x$ & $x$ & $x$ & $x$ & $x$ & $\sqrt{ }$ \\
\hline 4 & Cultural Knowledge & $x$ & $\sqrt{ }$ & $\sqrt{ }$ & $\sqrt{ }$ & $x$ & $x$ & $x$ & $\sqrt{ }$ & $x$ \\
\hline 5 & Pedagogical Skills. & $x$ & $\sqrt{ }$ & $x$ & $\sqrt{ }$ & $x$ & $\sqrt{ }$ & $\sqrt{ }$ & $x$ & $x$ \\
\hline 6 & Content Subjects. & $x$ & $\sqrt{ }$ & $\sqrt{ }$ & $\sqrt{ }$ & $\sqrt{ }$ & $\sqrt{ }$ & $\sqrt{ }$ & $x$ & $\sqrt{ }$ \\
\hline 7 & Psychological Knowledge. & $\sqrt{ }$ & $x$ & $\sqrt{ }$ & $x$ & $x$ & $\sqrt{ }$ & $\sqrt{ }$ & $x$ & $x$ \\
\hline 8 & Research Skills. & $x$ & $\sqrt{ }$ & $x$ & $x$ & $x$ & $x$ & $x$ & $x$ & $x$ \\
\hline 9 & Community Service. & $x$ & $\sqrt{ }$ & $x$ & $x$ & $x$ & $x$ & $x$ & $x$ & $x$ \\
\hline 10 & Quality Education. & $\sqrt{ }$ & $\sqrt{ }$ & $x$ & $x$ & $x$ & $x$ & $x$ & $x$ & $x$ \\
\hline 11 & $\begin{array}{l}\text { Language Acquisition } \\
\text { Theories. }\end{array}$ & $x$ & $x$ & $\sqrt{ }$ & $\sqrt{ }$ & $x$ & $x$ & $x$ & $x$ & $x$ \\
\hline 12 & $21^{\text {st }}$ Century skills. & $x$ & $x$ & $\sqrt{ }$ & $x$ & $x$ & $x$ & $x$ & $x$ & $\sqrt{ }$ \\
\hline 13 & $\begin{array}{l}\text { Language \& Cultures } \\
\text { Assessments }\end{array}$ & $x$ & $\sqrt{ }$ & $\sqrt{ }$ & $\sqrt{ }$ & $x$ & $\sqrt{ }$ & $\sqrt{ }$ & $x$ & $x$ \\
\hline
\end{tabular}




\begin{tabular}{|c|c|c|c|c|c|c|c|c|c|c|}
\hline \multirow[t]{2}{*}{ No } & \multirow{2}{*}{$\begin{array}{l}\text { Internationalized } \\
\text { Standards }\end{array}$} & \multicolumn{9}{|c|}{ Referenced Standards } \\
\hline & & $\begin{array}{l}\text { SD } \\
\text { S }\end{array}$ & $\begin{array}{l}\text { NA } \\
\text { RS } \\
\end{array}$ & $\begin{array}{l}\text { NEC } \\
\text { ATE }\end{array}$ & $\begin{array}{l}\text { ACT } \\
\text { FL } \\
\end{array}$ & $\begin{array}{l}\mathbf{C E} \\
\mathbf{A P}\end{array}$ & $\begin{array}{l}\text { AP } \\
\text { ST }\end{array}$ & $\begin{array}{l}\text { CE } \\
\text { TF }\end{array}$ & $\begin{array}{l}2 \\
1^{\text {st }} \\
\end{array}$ & $\begin{array}{l}\text { SD } \\
\text { Gs }\end{array}$ \\
\hline 14 & $\begin{array}{l}\text { Clinical Partnerships and } \\
\text { Practicum. }\end{array}$ & $x$ & $x$ & $x$ & $x$ & $\sqrt{ }$ & $x$ & $x$ & $x$ & $x$ \\
\hline 15 & $\begin{array}{l}\text { Candidate Quality and } \\
\text { Selectivity. }\end{array}$ & $x$ & $x$ & $x$ & $x$ & $\sqrt{ }$ & $x$ & $x$ & $x$ & $x$ \\
\hline 16 & Provider Quality & $x$ & $x$ & $x$ & $x$ & $\sqrt{ }$ & $x$ & $x$ & $x$ & $x$ \\
\hline 17 & $\begin{array}{l}\text { Supportive } \quad \text { Learning } \\
\text { Environments. }\end{array}$ & $x$ & $x$ & $x$ & $x$ & $x$ & $\sqrt{ }$ & $x$ & $x$ & $x$ \\
\hline 18 & Cooperate Professionally. & $x$ & $x$ & $x$ & $x$ & $\times$ & $\sqrt{ }$ & $\sqrt{ }$ & $\sqrt{ }$ & $x$ \\
\hline 19 & Critical thinking. & $x$ & $x$ & $x$ & $x$ & $x$ & $x$ & $x$ & $\sqrt{ }$ & $x$ \\
\hline 20 & Creativity. & $x$ & $x$ & $x$ & $x$ & $x$ & $x$ & $x$ & $\sqrt{ }$ & $x$ \\
\hline 21 & $\begin{array}{l}\text { Leadership } \\
\text { Responsibility. }\end{array}$ & $x$ & $x$ & $x$ & $x$ & $x$ & $x$ & $x$ & $\sqrt{ }$ & $x$ \\
\hline 22 & Technological Literacy. & $\sqrt{ }$ & $\sqrt{ }$ & $x$ & $x$ & $x$ & $x$ & $x$ & $\sqrt{ }$ & $x$ \\
\hline 23 & Environmental Literacy. & $x$ & $x$ & $x$ & $x$ & $x$ & $x$ & $x$ & $\sqrt{ }$ & $x$ \\
\hline 24 & Global Awareness. & $x$ & $x$ & $x$ & $x$ & $x$ & $x$ & $\times$ & $\sqrt{ }$ & $x$ \\
\hline
\end{tabular}

Table 3 shows the compatibility of the Internationalized Standards to the national and international 9 referenced standards. As displayed in the matrix, the Internationalized Standards are compatible to the 9 referenced standards. This result assures that Internationalized Standards meet the national and international standards.

\section{Table 4: Internationalized Standards Ranking}

\begin{tabular}{lllll}
\hline No & Standards & Compatibility Frequency & \\
& & n. & $\%$ & Ran \\
& & & $\mathrm{k}$ \\
\hline 1 & International Accreditation Standards. & 3 & 33.3 & 4 \\
2 & Competing Nationally and Internationally. & 1 & 11.1 & 6 \\
3 & National and International Labor Market. & 2 & 22.2 & 5 \\
4 & Cultural Knowledge & 4 & 44.4 & 3 \\
5 & Pedagogical Skills. & 4 & 44.4 & 3 \\
6 & Content Subjects. & 7 & 77.8 & 1 \\
7 & Psychological Knowledge. & 4 & 44.4 & 3 \\
8 & Research Skills. & 4 & 44.4 & 3 \\
9 & Community Service. & 1 & 11.1 & 6 \\
10 & Quality Education. & 1 & 11.1 & 6 \\
11 & Language Acquisition Theories. & 2 & 22.2 & 5 \\
12 & 21 ${ }^{\text {st }}$ Century skills. & 2 & 22.2 & 5 \\
13 & Language \& Cultures Assessments & 5 & 55.6 & 2 \\
14 & Clinical Partnerships and Practicum. & 1 & 11.1 & 6 \\
15 & Candidate Quality and Selectivity. & 1 & 11.1 & 6 \\
16 & Provider Quality & 1 & 11.1 & 6
\end{tabular}


No Standards
Compatibility Frequency

n.

17 Supportive Learning Environments.

18 Cooperate Professionally.

19 Critical Thinking.

20 Creativity.

21 Leadership and Responsibility.

22 Technological Literacy.

23 Environmental Literacy.

24 Global Awareness.

\begin{tabular}{ll}
$\%$ & $\begin{array}{l}\text { Ran } \\
\mathrm{k}\end{array}$ \\
\hline 11.1 & 6 \\
33.3 & 4 \\
11.1 & 6 \\
11.1 & 6 \\
11.1 & 6 \\
33.3 & 4 \\
11.1 & 6 \\
11.1 & 6 \\
\hline
\end{tabular}

Table 4 shows that twelve standards namely; Competing Nationally and Internationally, Community Service, Quality Education, Practicum, Candidate Quality, Provider Quality, Supportive Learning Environments, Critical Thinking, Creativity, Leadership, Environmental Literacy and Global Awareness gained compatibility percentage (11.1\%) to occupy the sixth rank. Three standards namely; National and International Labor Market., Language Acquisition Theories and $21^{\text {st }}$ Century skills gained compatibility percentage (22.2\%) to be placed in the fifth rank. Three standards namely; International Accreditation Standards, Cooperate Professionally and Technological Literacy gained compatibility percentage $(33.3 \%)$ to be placed in the fourth rank. Four standards namely; Cultural Knowledge, Pedagogical Skills, Psychological Knowledge and Research Skills gained compatibility percentage (44.4\%) to be placed in the third rank. One standard namely; Language and culture Assessment gained compatibility percentage $(55.6 \%)$ to be placed in the second rank. One standard namely; Content Subjects gained compatibility percentage (77.8\%) to be placed in the first rank. Based on these results, it could be concluded that the Internationalized Standards stress the importance of content subject or EFL competency. Similarly, EFL assessments should focus on language and culture. The rest of the standards gained moderate or low compatibility percentages. Accordingly, most of these standards were merged and restated to match more referenced standards. To increase the compatibility percentages, the 24 standards were restated to be 7 standards. 
The Development of a Suggested Internationalized Curriculum for Egyptian

Prospective EFL Teachers

Table 5: Credits, Courses and Percentage of the Internationalized Standards

\begin{tabular}{lllll}
\hline No. & Internationalized Standards & Credits & Courses & \% \\
\hline 1 & Content Subject Knowledge and Skills & 84 & 42 & $60 \%$ \\
2 & $\begin{array}{l}\text { Instructional Pedagogical Knowledge } \\
\text { and Skills }\end{array}$ & 14 & 7 & $10 \%$ \\
3 & $\begin{array}{l}\text { Psychological Pedagogical Knowledge } \\
4\end{array}$ & 7 & 4 & $5 \%$ \\
5 & Digitalized Knowledge and Skills & 7 & 4 & $5 \%$ \\
& Universal Educational Background & 7 & 4 & $5 \%$ \\
6 & Knowledge & 7 & 5 & $5 \%$ \\
7 & World Cultural Knowledge & 14 & 4 & $10 \%$ \\
\hline Total & Teaching Practicum & 140 & 70 & $100 \%$ \\
\hline
\end{tabular}

Table 5 displays the Content Subject Knowledge and Skills standard was given 84 credits, 42 courses and weight percentage 60\%. Instructional Pedagogical Knowledge and Skills standard was given 14 credits, 7 courses and weight percentage $10 \%$. Psychological Pedagogical Knowledge standard was given 7 credits, 4 courses and weight percentage 5\%. Digitalized Knowledge and Skills standard was given 7 credits, 4 courses and weight percentage 5\%. Universal Educational Background Knowledge standard gained 7 credits, 4 courses and weight percentage 5\%. World Cultural Knowledge standard gained 7 credits, 4 courses and weight percentage 5\%. Teaching Practicum standard gained 14 credits, 4 courses and weight percentage $10 \%$. Such results are in line with Graves (2009, p. 115) who suggests a framework for curriculum planning for Second Language Teaching Education (SLTE) that focuses on: who will be taught [learning], what will be taught [content subject], how it will be taught [teaching/instruction] and how what is learned will be evaluated [assessment]. In addition, Johnston and Goettsch (2000) propose four dimensions that need to be addressed in designing and revising SLTE programs: the content of second language teacher education (SLTE), the structures of SLTE programs must allow student-teachers how to use the content, the sequencing of content and form that is most conducive to effective learning, and the articulation between teacher education and actual teaching. In Chinese context, Ping (2015, p. 153) describes the Chinese EFL teacher education curriculum of the four year BA program, the compulsory taught courses include General English, Advanced General English, English Grammar, English Listening, English Speaking, English writing, Translation, Extensive Reading, English Listening, British Culture and Society, British and American Literature, Psychology, 
Basic Principles of Education, English Teaching Methodology, Testing, and Concise Linguistics. In addition to a three-month practicum in 20 local schools in the final year of the program. It is noteworthy, practicum was given $10 \%$ out of the total curriculum credits which may go in line with Darling-Hammond (2006) whom claims that effective teacher education programs need to ensure that pre-service teachers have sufficient time to apply what they have learned.

\section{Table 6: ILOs of the Internationalized Curriculum}

\begin{tabular}{lllllll}
\hline Domains & Knowledge & Professional & Intellectual & General & International & $\begin{array}{l}\text { Total } \\
\text { ILOs }\end{array}$ \\
\hline ILOs & 80 & 60 & 79 & 5 & 5 & 229 \\
\hline
\end{tabular}

Table 6 displays that the total curriculum ILOs are 229. ILOs were stated. Knowledge domain gained 80 ILOs. Professional domain was given 60 ILOs. Intellectual domain was given 79 ILOs. General domain was given 5 ILOs. Finally, the international domain was given 5 ILOs. Guided by these ILOs, the suggested Internationalized Curriculum for Egyptian Secondary School EFL Teachers' Education was tailored.

Table 7: EFL Experts' Evaluation of the Internationalized Standards (Total)

\begin{tabular}{lll}
\hline Ratings & Total Frequency and Percentages & \\
& Number & Percentage \\
\hline V. Good & 97 & $84.3 \%$ \\
Good & 15 & $13.1 \%$ \\
Poor & 3 & $2.6 \%$ \\
\hline Total & 115 & $100 \%$ \\
\hline
\end{tabular}

Table 7 shows that most of EFL experts $(84.3 \%)$ considered the Internationalized Standards were very good and the same experts considered the same the standards as good (13.1\%). The Internationalized Standards were estimated as poor based on the percentage of estimation (2.6\%). In light of EFL experts' estimations, it could be concluded that the Internationalized Standards are well-stated, feasible, relevant, important and sufficient.

Table 8: EFL Experts' Evaluation of the Internationalized EFLTEC ILOs

\begin{tabular}{llllllll}
\hline No & Evaluation Areas & \multicolumn{2}{c}{ Rate Frequency } & \multicolumn{3}{l}{} \\
& & \multicolumn{2}{c}{ Very Good } & Good & \multicolumn{2}{c}{ Poor } \\
& & n. & $\%$ & n. & $\%$ & n. & $\%$ \\
\hline 1 & Relevancy of ILOs & 15 & 88.2 & 2 & 3.9 & 0 & 0 \\
2 & Importance of ILOs & 15 & 88.2 & 2 & 3.9 & 0 & 0 \\
3 & Sufficiency of ILOs & 14 & 82.4 & 2 & 3.9 & 1 & 1.9 \\
\hline \multicolumn{2}{l}{ Total Frequency (Max.17 $\times 3=51)$} & 44 & $86.3 \%$ & 6 & $11.8 \%$ & 1 & $1.9 \%$ \\
\hline
\end{tabular}


Table 8 illustrates that the ILOs of the EFLTEC proved relevant as they were estimated very good $(88.2 \%)$ and good (3.9\%). No percentage was given to poor $(0 \%)$. Moreover, the ILOs of the EFLTEC were considered important where the very good percentage was $(88.2 \%)$ and good was $(3.9 \%)$. No poor percentage $(0 \%)$ was given. While the ILOs of the EFLTEC proved sufficient since the very good percentage was $(82.4 \%)$ and good was (3.9\%), the poor percentage was (2.6\%). Based on the EFL experts' estimations, it could be concluded that the ILOs of the EFLTEC are relevant, important and sufficient.

Table 9: EFL Experts' Evaluation of the Internationalized EFLTEC Courses

\begin{tabular}{llllllll}
\hline No & Evaluation Areas & \multicolumn{3}{c}{ Rate Frequency } & & \multicolumn{2}{l}{} \\
& & \multicolumn{2}{c}{ Very Good } & Good & \multicolumn{2}{l}{ Poor } \\
& & n. & $\%$ & n. & $\%$ & n. & $\%$ \\
\hline 1 & Relevancy of Courses & 16 & 94.1 & 1 & 5.9 & 0 & 0 \\
2 & Importance of Courses & 15 & 88.2 & 2 & 11.8 & 0 & 0 \\
3 & Sufficiency of Courses & 13 & 76.5 & 4 & 23.5 & 0 & 0 \\
$4 \quad$ Distribution of Courses & 14 & 82.4 & 2 & 11.8 & 1 & 5.9 \\
\hline Total Frequency & 58 & $85.3 \%$ & 9 & $13.2 \%$ & 1 & $1.5 \%$ \\
$($ Max.17 $\times 4=68) \quad$ & & & & & & \\
\hline
\end{tabular}

Table 9 shows that the courses of the EFLTEC proved relevant as they were estimated very good $(94.1 \%)$ and good $(5.9 \%)$. No percentage was given to poor $(0 \%)$. Likewise, the courses of the EFLTEC were considered important where the very good percentage was $(88.2 \%)$ and good was $(11.8 \%)$. No percentage was given to poor $(0 \%)$. The courses of the EFLTEC proved sufficient since the very good percentage was $(76.5 \%)$ and good was $(23.5 \%)$. No percentage was given to poor $(0 \%)$. The courses of the EFLTEC were well-distributed since the very good percentage was $(82.4 \%)$ and good was (11.8\%). Poor estimation percentage was $(5.9 \%)$. Based on the EFL experts' estimations, it could be decided that the courses of the EFLTEC are relevant, important, sufficient, well-distributed.

Table 10: EFL Experts' Evaluation of the Whole Internationalized EFLTEC

\begin{tabular}{|c|c|c|c|c|c|c|c|}
\hline & \multirow[t]{3}{*}{ Evaluation Areas } & \multicolumn{6}{|c|}{ Rate Frequency } \\
\hline & & \multicolumn{2}{|c|}{ Very Good } & \multicolumn{2}{|c|}{ Good } & \multicolumn{2}{|c|}{ Poor } \\
\hline & & n. & $\%$ & n. & $\%$ & n. & $\%$ \\
\hline 1 & National Requirements & 17 & 100 & 0 & 0 & 0 & 0 \\
\hline 2 & International Requirements & 13 & 76.5 & 4 & 23.5 & 0 & 0 \\
\hline \multicolumn{2}{|c|}{ Total Frequency $($ Max.17 × $2=34)$} & 30 & $85.3 \%$ & 4 & $13.2 \%$ & 0 & $0 \%$ \\
\hline
\end{tabular}


Table 10 shows that the Internationalized EFLTEC as a whole met the national requirements of the educational reform in Egypt where the V. Good percentage was (100\%). Further, the curriculum matched the international requirements since the V. Good percentage was $(76.5 \%)$ and the Good percentage was (23.5\%). No Poor ratings were given. Based on the EFL experts' estimations, it could be concluded that the Internationalized EFLTEC as a whole met the national and international requirements.

Table 11: EFL Experts' Evaluation of the Internationalized Standards (Items)

\begin{tabular}{llllllll}
\hline \multirow{2}{*}{ No } & Evaluation Areas & \multicolumn{3}{c}{ Evaluation Rate Frequency } & \multicolumn{2}{l}{} \\
& & \multicolumn{2}{c}{ Very Good } & Good & Poor & \\
& & n. & $\%$ & n. & $\%$ & n. & $\%$ \\
\hline 1 & Standards Statement (Max.17) & 14 & 82.3 & 2 & 11.8 & 1 & 5.9 \\
2 & Standards Feasibility (Max.17) & 15 & 88.2 & 2 & 11.8 & 0 & 0 \\
3 & Standards Relevancy (Max.17) & 12 & 70.5 & 5 & 29.4 & 0 & 0 \\
4 & Standards Importance (Max.17) & 13 & 76.5 & 4 & 23.5 & 0 & 0 \\
5 & Standards Sufficiency (Max.17) & 13 & 76.5 & 2 & 11.8 & 2 & 11.8 \\
\hline \multicolumn{2}{l}{ Total Frequency (Max.17 $\times 5=115)$} & 97 & $84.4 \%$ & 15 & $13 \%$ & 3 & $2.6 \%$ \\
\hline
\end{tabular}

Table 11 displays that while the statement of Internationalized Standards was very good $(82.3 \%)$ and the same item was rated as good $(11.8 \%)$, the statement of Internationalized Standards was considered poor $(5.9 \%)$. Accordingly, the Internationalized Standards were wellstated in light of EFL Experts' ratings. In addition, the Internationalized Standards were seen feasible (V. Good $=88.2 \%)$ and $($ Good $=11.8 \%)$ as rated by EFL experts. No poor rating was given $(0 \%)$. Similarly, the Internationalized Standards were relevant (V. Good $=70.5 \%)$ and (Good $=29.4 \%)$ as rated by EFL experts. No poor rating was mentioned $(0 \%)$. Likewise, the Internationalized Standards were estimated important (V. Good $=70.5 \%)$ and $($ Good $=29.4 \%)$ as rated by EFL experts. No poor rating was recognized $(0 \%)$. Whereas the Internationalized Standards were estimated as sufficient (Very Good $=76.5 \%)$, $(\mathrm{Good}=11.8 \%)$ and only $(3.6 \%)$ of the estimation was poor.

Coupling the qualitative results in Tables (3, 4 and 5) to the quantitative results shown in Tables $(6,7,8,9,10$ and 11) answers the second question: What are the basic features of the suggested internationalized EFLTEC? The results illustrated the national and international standards of EFL teachers' education curriculum, the weights of each standard, curriculum courses, curriculum ILOs and the courses to be taught at each level of study. All these features and the other detailed features in Appendix (12) paved the way for suggesting the 
internationalized curriculum for Egyptian secondary school EFL teachers' education.

\section{Discussion of Results}

Firstly, this research found that the current EFL majors were not satisfied with the current teacher education curriculum offered by the Faculty of Education at October 6 University which is similar to other programs offered at many Egyptian faculties of education. This result was expected since almost all EFL teacher education curricula were developed to meet national requirements of past times which differ greatly from the requirements of the present digital and internationalized age. In this concern, Zein (2018, p.14) argued that new English teacher education curricula must enable prospective English language teachers to face an unknown and increasingly globalized future. This finding is consistent with the findings of the evaluative studies carried out by Yamada (2018), Molstad and Karseth (2016), Ping (2015), Nguyen (2013), Urbanovic and Wilkins (2013), Abaszadeh (2012), Han (2010), Coskun \& Daloglu (2010), Chong and Cheah (2009), Zou (2009) and Peacock (2009). Secondly, EFL experts approved the suggested internationalized EFL teacher education curriculum. Such an approval may be rendered to the systematic procedures of designing the suggested program. The suggested program based on document analyses of 9 national and international references such as the Sustainable Development Strategy (SDS), National Academic Reference Standards (NARS), American Council on the Teaching of Foreign Language (ACTFL), National Council for Accreditation of Teacher Education (NCATE), the Standards of the Council for Accreditation of Educator Preparation CAEP, the Australian Professional Standards for Teachers (APST), Cambridge English Teaching Framework (CETF), Sustainable Development Goals (SDGs) and $21^{\text {st }}$ Century Skills. Accordingly, the suggested internationalized curriculum for Egyptian secondary school EFL teachers' education is ready to be recognized by the Egyptian authorities for modifications and implementation. Finally, it is recommended to carry out the same research project on a large scale or to be sent to all Egyptian Faculties of Education for more modifications or adaptation.

\section{Research Conclusion}

Based on the review of literature, the internationalization of higher education is growing rapidly, and many publications highlighted the importance of this procedure. The current teacher education curricula (TEC) has been targeted by the Egyptian reform agenda. One possible 


\section{Mohamed Farrag Ahmed Badawi}

way to reform the current TEC is to be reshaped to meet the national and international requirements. Thus, this research project attempted to evaluate the current EFL teacher education curricula and to suggest an internationalized curriculum for Egyptian secondary school EFL teachers' education. The findings revealed that EFL majors were not satisfied with the current teacher education curriculum offered by the Faculty of Education at October 6 University. Additionally, it was revealed that the current EFLTEC was neither tuned to most of the requirements of the national educational reform nor to the core international standards. For developing the suggested EFLTE curriculum, nine recognized referenced documents were analyzed to elicit the national and the internationalized standards against which the suggested internationalized EFL teacher education curriculum was developed. More importantly, the suggested internationalized EFL teacher education curriculum was approved by the majority of EFL experts. The complete internationalized EFLTEC (see Appendix12) is ready to be recognized by the Egyptian authorities for implementation or modifications. 


\section{References}

Abaszadeh, A. (2012). Comparing teachers' needs and teacher trainers' priorities. Proceedings of the $10^{\text {th }}$ international TELLSI conference (pp. 53-66). Tehran, Iran.

ACTFL (2013). American Council on the Teaching of Foreign Language. https://www.actfl.org/sites/default/files/CAEP/ACTFLCAEPStandards2 013_2015.pdf

Altbach, P. \& Knight, J. (2007). The internationalization of higher education: Motivations and realities. Journal of Studies in International Education, 11(3-4), 290-305.

APST (2011). Australian Professional Standards for Teachers. https://educationstandards.nsw.edu.au/wps/wcm/connect/8658b2fa62d3-40ca-a8d902309a2c67a1/australian-professional-standardsteachers.pdf?MOD=AJPERES\&CVID

ARE, Strategic Plan for Pre-University Education Reform in Egypt 2014-2030. http://planipolis.iiep.unesco.org/upload/Egypt_Strategic_Plan_\%20PreU niversity_Education_2014-2030_eng.pdf

Atmowardoyo, H. (2018). Research Methods in TEFL Studies: Descriptive Research, Case Study, Error Analysis, and R \& D. Journal of Language Teaching and Research, 9(1), 197-204. DOI: http://dx.doi.org/10.17507/j1tr.0901.25

Beelen, J. \& Jones, E. (2015). Redefining internationalization at home. In A. Curaj, L. Matei, R. Pricopie, J. Salmi, \& P. Scott (Eds.), The European higher education area: Between critical reflections and future policies (Vol. 1, pp. 59-72). Doi: 10.1007/978-3-319-20877-0_5

Betts, J., Andrew, C., \& Rice, L. (2003). Determinants of student achievement: New evidence from San Diego: Public policy Institute of California.

Betty, Leask (2001). Bridging the Gap: Internationalizing University Curricula. Journal of Studies in International Education, 5(2):100-115. DOI: $10.1177 / 102831530152002$

Borg, S. (2018). Teacher evaluation: Global perspectives and their implications for English language teaching: A literature review. British Council, London: SW1A 2BN, UK www.britishcouncil.org

Bowen, G. (2009). Document Analysis as a Qualitative Research Method, Qualitative Research Journal, 9(2), 27-40, https://doi.org/10.3316/QRJ0902027

CAEP (2013). Standards of the Council for Accreditation of Educator Preparation. http://caepnet.org/ /media/Files/caep/standards/caepstandards-one-pager0219.pdf?la=en

CETF (2014). Cambridge English Teaching Framework. https://www.cambridgeenglish.org/Images/172992-full-leveldescriptors-cambridge-english-teaching-framework.pdf 


\section{Mohamed Farrag Ahmed Badawi}

Chong, S. \& Cheah, H. (2009). A values, skills and knowledge framework for initial teacher preparation programs. Australian Journal of Teacher Education, 34(3), 1-16.

Corbin, J. \& Strauss, A. (2008). Basics of qualitative research: Techniques and procedures for developing grounded theory ( $3^{\text {rd }} \mathrm{Ed}$.). Thousand Oaks, CA: Sage.

Coskun, A., \& Daloglu, A. (2010). Evaluating an English Language Teacher Education Program through Peacock's Model. Australian Journal of Teacher Education, 35(6). http://dx.doi.org/10.14221/ajte.2010v35n6.2

Crosling, G. and Edwards, R. (2008). Internationalizing the curriculum: the implementation experience in a Faculty of Business and Economics. Journal of Higher Education Policy and Management, 30 (2), 107-121. http://dx.doi.org/10.1080/13600800801938721

Darling-Hammond, L. (2006). Powerful teacher education: Lessons from exemplary programs. San Francisco: Jossey-Bass.

De Wit, H., Hunter, F., Howard, L. \& Egron-Polak, E. (eds.) (2015). Internationalisation of Higher Education. Brussels: European Parliament.

Denscombe, M. (2010). The Good Research Guide: For small-scale social research projects. Maidenhead: Open University Press.

Dykes, O., Gilliam, B., Neel, J., \& Everling, K. (2012). Peeking inside Pandora's Box: One University's Journey into the Redesign of Teacher Educator Preparation. (ERIC Document Reproduction Service No. EJ978290).

Eldik, K. (2011). Challenges in the internationalization of higher education. The Modern University for Business \& Science. Beirut. http://heic.info/assets/templates/heic2011/papers/13-Kamal_Eldik.pdf

Ennew, C. and Greenaway, D. (2012). The globalization of higher education. New York: Palgrave Macmillan.

Eren, A. \& Tezel, K. (2010). Factors influencing teaching choice, professional plans about teaching, and future time perspective: A mediational analysis. Teaching and Teacher Education, 26(7), 1416-28.

Goktepe, T. (2015): A critical analysis of foreign language teacher education practices in Turkey, International Journal of Languages Education and Teaching, (3)1, p. 128-143.

Graves, K. (2009). The curriculum of second language teacher education. In A. Burns\& J. C. Richards (Eds.), The Cambridge guide to second language teacher education (pp. 115-124). New York: Cambridge University Press.

Green, M. \& Schoenberg, R. (2006). Where faculty live: Internationalizing the disciplines. Washington. DC: American Council on Education.

Han, Y., (2010). The impact of pre-service teacher training on the later teaching performance. Teacher Education Study, 22(2), 134-144.

Hudzik, J. (2015). Comprehensive internationalization: Institutional pathways to success. London: Routledge. 


\section{Prospective EFL Teachers}

Hunter, B., White, G. \& Godbey, G. (2006).What Does It Mean to Be Globally Competent? Journal of Studies in International Education, 10 (3), 267285

Johnston, B. \& Goettsch, K. (2000). In search of the knowledge base of language teaching: Explanations by experienced teachers. Canadian Modern Language Review, 56(3), 437-468.

Jones, E. \& Killick, D. (2013). Graduate attributes and the internationalized curriculum: Embedding a global outlook in disciplinary learning outcomes. Journal of Studies in International Education, 17(2), 165182. Doi: $10.1177 / 1028315312473655$

Kehm, B. \& Teichler, U. (2007). Research on internationalization in higher education. Journal of Studies in International Education, 11, 260-273.

Kim, W. (2005). Cultivating and securing qualified teachers. MOE unpublished manuscript, Seoul.

Knight, J. (2002). Trade in higher education services: The implications of GATS. London, England: The Observatory on Borderless Higher Education.

Knight, J. (2007). Cross-border higher education: Issues and implications for quality assurance and accreditation. In Global University Network for Innovation (GUNI). Higher education in the world 2007: Accreditation for quality assurance: What is at stake? (pp. 134-146), New York: Palgrave Macmillan.

Knight, J. (2008). Higher education in turmoil: The changing world of internationalization. Boston, MA: Sense.

Kreber, C. (2009). Different perspectives on internationalization in higher education. New Directions for Teaching and Learning, 118, 1-14. Doi: $10.1002 / \mathrm{tl} .348$.

Leask, B. (2013). Internationalizing the curriculum in the discipline: Imagining new possibilities. Journal of Studies in International Education, 17(2), 103-118. Doi: 10.1177/1028315312475090

Leask, B. (2015). Internationalizing the Curriculum. Abingdon: Routledge.

Lee, B., \& Cai, H. (2018). Evaluation of an Online "Internationalization at Home" Course on the Social Contexts of Addiction. Journal of Studies in International Education. (September 2018), 1-24. https://doi.org/10.1177/1028315318797155

Liang, L., Ebenezer, J., \& Yost, D. (2010). Characteristics of pre-service teachers. Journal of Science Education and Technology, 19(1), 11-17.

Lueg, K. (2018). The internationalization of higher education in Europe: a discussion of English as a medium of instruction and its implications for (in) equalities. Culture, Practice \& Europeanization, 3(1), 47-67.

Maringe, F. (2010). 'The Meanings of Globalisation and Internationalization in HE: Findings from a World Survey', in F. Maringe and N. Foskett 
(eds.) Globalization and Internationalization in Higher Education, London: Continuum, 17-34.

Maringe, F., Foskett, N., (2013). Globalization and internationalization in higher education: theoretical, strategic and management perspectives. London: Bloomsbury Academic.

Miclea, M. (2003). Institutional-Level Reform and the Bologna Process: The Experience of Nine Universities in South East Europe. Higher Education in $\quad$ Europe, 28(3), 259-272. http://dx.doi.org/10.1080/0379772032000119919

Molstad C., and Karseth, B. (2016). National curricula in Norway and Finland: The role of learning outcomes, European Educational Research Journal, 15(3), 329-344.

NARS (2014). National Academic Reference Standards. http://naqaae.eg/wpcontent/uploads/2014/PDF/29.pdf

NCATE (2008). National Council for Accreditation of Teacher Education. http://www.ncate.org/ /media/Files/caep/accreditation-resources/ncatestandards-2008.pdf?la=en

Nguyen, M. (2013). The curriculum for English language teacher education in Australian and Vietnamese universities. Australian journal of teacher education, 38 (11), 33-53.

Pacific Policy Research Center (2015). $21^{\text {st }}$ Century Skills for Students and Teachers. https://www.slideshare.net/royalchildacademylapulapu/the21st-century-teacher-and-learner

Partington, G. (2001). Qualitative research interviews: Identifying problems in technique. Issues in Educational Research, 11(2)|, 32-44.

Peacock, M. (2009). The evaluation of foreign-language-teacher education programs. Language Teaching Research, 13(3), 259-78.

Ping, W. (2015). An Evaluation of the preservice English teacher education in a university in China: Pros and cons from an insider's journey of learning. JoP, 6 (1), 151 -174. DOI 10.1515/jped-2015-0008

Rapley, T. (2007). Doing conversation, discourse and document analysis. London: Sage.

SDGs (2015). Sustainable Development Goals. http://www.un.org/sustainabledevelopment/sustainable-developmentgoals

Shay, S. (2013). Conceptualizing curriculum differentiation in higher education: A sociology of knowledge point of view. British Journal of Education 34(4), 563-582.

Spolsky, B., \& Sung, K., (2015). Secondary school English education in Asia: From policy to practice. London and New York: Routledge.

Stroupe, R., and Kimura, K. (Eds.). (2015). ASEAN Integration and the role of English language teaching. Phnom Penh, Cambodia: IELTS.

Sustainable Development Strategy (SDS): Egypt Vision 2030. http://arabdevelopmentportal.com/sites/default/files/publication/sds_egy pt_vision_2030.pdf 


\section{Prospective EFL Teachers}

Tahira, J. \& Masha, K. (2015). Internationalization of Higher Education: Potential Benefits and Costs. International Journal of Evaluation and Research in Education (IJERE), 4(4), 196-199.

Urbanovic, J. \& Wilkins, S. (2013). Internationalisation as a strategy to improve the quality of higher education in small states: Stakeholder perspectives in Lithuania. Higher Education Policy, 26, 373-396.

Vainio-Mattila, A. (2009). Internationalizing Curriculum: A New Kind of Education? New Directions for Teaching and Learning, 118 (2), 95-103.

Wei, C., \& Pecheone, L. (2010) Assessment for learning in pre-service teacher education performance-based assessments. In M. M. Kennedy (Ed.). Teacher assessment and the quest for teacher quality. San Francisco Co: Cambridge University Press. Jossey Bass.

Yamada, M. (2018). Evaluation of an EFL Teacher Training Program in Japan, Journal of Applied Social Science, 12(1), 25-45. Doi. $10.1177 / 1936724418755420$

Zein, S. (2018). Preparing Asian English teachers in the global world. In S. Zein, \& R. Stroupe. (Eds.). English language teacher preparation in Asia: Policy, research and practice, 1-15. New York: Routledge.

Zou, W. (2009). The study on the pre-service teacher education for Chinese basic education. Foreign language teaching theory and practice, 4(1), 16-19. 